\title{
Two Main Linguistic and Semantic Approach in Islamic Theologoical Tradition
}

\author{
Ibrahim BOR \\ Mardin Artuklu University, Mardin, Turkey
}

\begin{abstract}
Theology is one of the main areas in which linguistics and semantics take up a significant space. The same issue also appears in the Islamic theological works known "kalam". There are two main semantical approaches regarding the theological doctrines in the Islamic thought. However the theological reasons are the primary aims in these semantical works, but they include serious philosophical and linguistic content. One of them is the main Islamic strand (orthodox Islam) represented by some astonishing Islamic scholars such as Ici, Guwaini, Şahristani, Ghazali, and Razi. According to this tradition, meaning is an inner state and a state of mind which is specified by the intent of the interlocutor or the author. The utterances have only an instrumentel role in speech. This approach can also be compared to the primary semantic view ranging from Aristotele to P. Grice-with some variations in the Western philosophical tradition. The second thesis is argued by the Mu'tazili sect who are called Islamic rationalists that objected to Ahl us-Sunnah in their prominent ideas. From Mu'tazila's point of view meaning should only be looked for among linguistic facts. There is no intentional content in the mind before the utterances. Meaning is produced within the structure of language itself and the conventional social context. In other words, meaning is nothing but the usage of the language. These two approaches also mean that there is going to arise different forms of interpretation in the theological perception. The aforementioned approach carries similarities with the approaches of Western thinkers like Wittgenstein and his followers. In this paper, the author deal with these two theological approaches by focusing on their linguistic and semantic views and comparing them with some modern western theories.
\end{abstract}

Keywords: semantic approach, inner/mental meaning, utterance, Ahl us-Sunnah, Mu'tazila

\section{Introduction}

Considering meaning as a mental content, it has a long history as far back as Aristotle. Aristotle defines writing as what happened in the voice, and that happened in the voice and the language as what happened in the mind's signs and symbols (Aristotele, 2002, p. 7). According to Aristotle, linguistic phrases refer directly to the mental meaning. Language, in general, is defined in three levels such as "mental", "verbal", and "written" by Plotinus. Since explaining the meaning into the mental contents has also an essential role in solving some problem of theology at the same time, the effect of this approach have lasted through to the Middle Age (Kretzman, 1967, pp. 362-363). According to this separation, mental meaning not only comes before verbal and written levels but also has no debt to them within its existence. As a matter of fact, presence of the other levels of language cannot be discussed without the dimension of inner/intentional meaning. Similarly, due to the fact

Ibrahim BOR, Associate Professor, Department of Philosophy, Faculty of Literature, Mardin Artuklu University. 
that meaning is given form by subject's intention, purpose, and belief, it cannot be explained thoroughly by conventional and social rules unlike other language levels.

Mental theories can also be considered as traditional approaches. ${ }^{1}$ According to the supporters of the traditional view, the meaning corresponds to mental contents as thought, opinion, idea, concept. ${ }^{2}$ From such a point of view, accepting concepts or ideas at any view means to embrace cognitive objects (Alexander, 1985, p. 236).

While Ahl us-Sunnah theologians represented by tendency of orthodox in Islamic thought have been facing problems related to eternal kalam's nature, they have found the solution by developing same opinions like the approach of inner/intentional meaning. Even if their efforts have a theological context in principle, they have also a philosophical explanation in terms of meaning and the nature of speech.

Mu'tazila theologians known by their efforts in explaining the basic claims of religion in Islamic philosophy on a rationalist way, have come out against Ahl us-Sunnah theologians likewise the approaches (like Wittgenstein and his followers) that explain the meaning with the usage and rules of language have made objection to mental/intentional meaning apprehension. ${ }^{3}$

The study aims to explain this subject along with Ghazali, who is the most effecter in Islamic thought mainly after his period, and afterwards one of the encyclopaedic thinkers Fahraddin-i Razi's thoughts in this assignment. In the study the issue criticized by an approach on the basis of Qadi Abdalcabbar that is the representation of Mu'tazila's point of view. ${ }^{4}$

\section{A General Framework of Ahl us Sunnah' Approach: Meaning is a Mental State}

Ahl us-Sunnah theologians accept speech acquisition in two different dimensions such as inner speech and verbal speech, the former tries to explain aspects of God's word such as meaning, knowledge and eternity while the latter takes aim at explaining phenomenological dimension reflected in human language level. Inner speech demonstrates a definition to refer to speaker's cognitive intention in principle. On the other hand, verbal speech is used to clarify all linguistic aspects becoming concrete as of voice, letter and wording; to define their physical aspects. Inner speech can be summarized as a meaning taking place of nafs(mind), which is said that most of the classical Sunni theologians come to an agreement on this definition (Ghazali, 1998, p. 76; Bakillani, 1986, p. 115; Ici, (dateless), 294; Guwaini, 1992, p. 108). In this way, inner speech has a mental(nafsi) meaning putting forward the speaker's intention, purpose, and request. It is said that this definition was made on purpose for the theologians who define inner speech as an intrinsic kalam (speech) at the same time. When we break the definition into the pieces with analytic research, it is defined that nafs is the reasonable inner part of human or just mental. "Taking place of" that is one of the important terms in a semantic way emphasizes a meaning out of all other speaker's prospect meanings with a clear intention and tendency into the mind, which makes the message transfer to the listener in a clear intentional and selective sense. Guwaini makes the definition clear in

\footnotetext{
${ }^{1}$ Hilary Putnam defines mental theory as traditional theory by referring "taking a meaning of a term as concept implies the meaning as mental" (Putnam, 1993, pp. 150, 161).

${ }^{2}$ Locke, among the ones who are accepted as the founders of not only the epistemology but also the semantics, is the most important representative of the mental theory. Locke refers all the cognitive contents to the term of "Idea". For Locke, "Idea" is used instead of all the mental objects such as thought, dream, concept or envision (Charles Landsman, 1976, p. 32).

${ }^{3}$ See for a general content of the paper, Ibrahim Bor. (2014) (Especially chapter II, 57-78).

${ }^{4}$ In this study is being focused on Mu'tazila's views over the approaches of Qad1 Abduljabbar who is accepted as the peak of the Mu'tazila thought. One of the main reasons of this is that the arguments in question have gained philosophical content mostly both for Mu'tazila and next periods.
} 
this way, "One realizes necessarily the meaning that obeyed in his nafs(mind) what if he commands someone in something. It is the inner speech which becomes clear in the mind and leads the listener to perceive in the same sense" (Guwaini, 1992, p. 109). According to Guwaini, for instance, "do it!" that is an order can be a request, advice or an offer in addition to that it can be a demand of carrying out an essential order. That's why the speaker's intention or purpose gives shape to the required meaning; in other words, the meaning of "taking place of mind" takes form within all the nuance cognitive orientation.

The point of speech means inner intention being understood by the listener. The crucial one out of the others in the nafs is the meaning of mental content known as referred meaning. All verbal sighs, words, letters and voices used by the speaker have an instrumental importance to identify the inner speech/meaning (Guwaini, 1992, pp. 109-110). Likewise, literal meaning is just an instrument to realize and transfer the intentional inner meaning. Right after he has defined the inner speech, for the instantiated instrumental dimension, Bakillani says "Inner speech exists in the forms of writing, voice, sigh and symbol" (Bakillani, 1986, p. 158).

Ahl us-Sunnah theologians including Ghazali take into consideration the relationship between meaning and utterance with the differences between denotation and referred. The purpose of expressing something is a reference that is behind the intention, which accordingly refers to the meaning. Now that denotation states the utterance coming from the tongue, the meaning into the significance of denotation is known as referred meaning. For instance, the order of "stand!" has necessarily a significant influence on a denotation. The semantic context of the order of "stand!" to be final is an intentional meaning sheltered into the speaker's intention. The inner speech implied as a referred meaning has a distinctive feature: all linguistic utterances are naturally different from letter and voice. As he shares the same opinions with the other theologians, Ici indicates: inner speech is different from utterances. For that reason, utterances change with regard to time, place and languages. That the linguistic utterance mentioned meaning - whichever language it is - is the one (Al-Ici, 1992, p. 294).

All of these characteristic features are detailed, which is that details correspond to epistemological, semantic and even physiological differences time to time. For instance, this intentional content must be distinguished from knowledge and will known as decision. Like the order of "stand!", that mentioned about the command wording which forms the act of speaking is a sort of a demand settled into the nafs (Ghazali, 1998, $p$. 77). Referred meaning which is inner cannot be understood with a denotation(sign). Denotation is one of the indicators to reach the referred meaning. However, it is not enough itself to signify what the referred meaning is. Denotation (that is defined as a sign from the approach of Saussure) and referred (that is defined as a signified) have completely different qualities. Discourse competence expressed as of denotation can be stated in different kinds of languages and can be uttered in a manner of different circumstances, thereby having a linguistic quality which is changeable and physical. On the contrary, since referred meaning is based on the speaker's intention in terms of mental feature, it is the dimension of meaning that is more objective and can be shared with people. Interestingly, this approach refers to something that is more objective and sharable based on common assumption in all minds, not subjective mentalism.

However, when we take into account Ghazali's example of fire $(1998$, p. 78$)$, meaning is not actually about mental process. In this way, referred does not refer to the meaning, but the realm of exterior related to meaning. Meaning comes in sight on condition of depending on contact through an exterior reference of the mind. For that reason, it is not difficult to realize that Ahl us-Sunnah theologians think indirectly about the reality of exterior part and something that is cognitive referring to itself in their explanation about inner 
meaning. Inner speech/meaning is completed by referring the reality of exterior part that exceeds the mental content. Mental purposes and intentions are accepted validly and significantly in terms of pointing to the reality. This result is inevitable among the other results that Ahl us Sunnah theologians want to reach. Likewise, neither propositions about God nor the content of divine kalam(speech) based on subjective cognitive contents can be a healthy way for theologians.

\section{Systematize of Ahl us-Sunnah's Approach: Ghazali and Razi}

Ghazali deals with intentionality of meaning entirely in his two works at different places. Al-İqtisat fil I'tiqad that is the earlier work points out more significantly the classical kalam(theological) view. Act of speech is a mental ability that cannot be reduced to something uttered, and the essence of this competence comes from the inner intentions. If one does not manage to utter something he wants, it doesn't mean he does not speak. The competence is as well different from abilities such as willing and thinking. For instance, Ghazali completely states that referred meaning pointing to the word is different from these kinds such as knowledge, will, and belief (Ghazali, 1998, p. 77). He makes a distinction between utterance and meaning: utterance refers to an entity that is shaped intentionally into the speaker's mind called as meaning. The concrete way of speech is basically utterance. And utterance consists of declarative expressions or act of speeches such as command, request, and prohibition. The content of knowledge or judgment propositions in an Aristotelian approach are declarative expressions known "khaber" referring to knowledge of speaker (1998, pp. 75-76). On the other hand, meaning is an inner content in the mind. Therefore, meaning does not always refer to something uttered. It is more importantly an intentional content transferred from the speaker to the listener over the linguistic expression. The intentional content points at meaning that is discriminated as referred and called as "inner speech" in theological discussions. By giving the example of order Ghazali says over: "command signs a request that must be fulfilled by the one listening to the order in the nafs" $(1998$, p. 76).

However, Ghazali is aware of the fact that there is a problem about accepting as content inner speech come before the word in the mind, and how to exist independently without voice and letters (1998, p. 78).

It is most probably reasonable to say that Marifetu'l Aqliyyah has a claim against the discussions made till the end of his period about kalam (speech). Ghazali mentions intensely about the relationships between language, thought and meaning in this work that he explains speech is a state of thought ability and utterance ability is a state of speech ability based on thought. Speech and thought have actually their own distinctive features, and so they cannot reduced to each other. However, these are two abilities that cannot live without each other and be independent with each other by no means. "Thought is not all a state of word or sign and spelling of voice and letters". It is the abstract comprehension ability of human (Ghazali, 2002, pp. 41-42). "The most supreme quality of thought is speech and the basis of the word" (2002, p. 42). The important thing about speech ability is not only related to comprehension but also alienable potential transferring to others by concretizing the comprehension. But, it does not come true to transfer and act out without the process of conceptualization through the comprehension thought (2002, p. 45).

It seems that Ghazali is concerned with two kinds of ability of thought. While the first one prioritizing the speech is abstract comprehension ability of human, the second one occurred exactly with the language is the act of thought. He draws attention the level of thought with those expressions: "The essence of man is the regardful, reasonable and perceiver nafs" (2002, p. 59). Man has potentially all thinkable states on the one side and there is a level of thought pertaining to severe relationship with speech on the other side. If meaning does not turn 
into utterance and reach to a level of audible, "that is the comprehensible thought picked up into the mind" (2002, p. 58). It is the utterance that speaker transfers the meaning to others with a beneficial and comprehensible expression.

Ghazali states the speech in the close relationship with thought, "It is the speech that means competence regularly combined of receptive thought called before utterance and born with the perception of mind" (2002, p. 53). In general as a characteristic of speech and thought the term of "nutuq" (discourse/speech) in the sentence deserves much more attention. The unity of speech and thought actually is a sort of term expressed as inseparableness with together. "Logos" is the best term corresponding to "nutuq" in Western thought.

Nutuq (ability of speech and thought) occurs into thought when mental and spiritual meaning combine with the letters. It becomes utterance when languages put it out (p. 57). The following expression of Ghazali makes the relationship between speech and thought much more clear, "meaning means thought when hiding into the room of thought. As it takes out of thought and comes close to utterance, it is the speech" (p. 53). There is needed a transmitter to turn the thought into the speech. The transmitter is the inner (logical) linguistic structure that is more of inclination to speech of the mind to turn the level of linguistic into the word. In addition to that, utterance needs lexical items and some kinds of expressions to become actual. These are organs such as mouth, teeth, laryngeal, and any other physical conditions and stuffs (p. 53).

Ghazali says that "utterance comprises of voice and letters" like the discrimination between phatic and rhetic of J. Austin. It is the actualization level of speech including meaning at the same time. Likewise, utterance is called as an exact speech with transferring the meaning, and being listened and understood by others. In other words, according to Ghazali, "utterance is an exact speech walking around languages" (pp. 57-58).

It is supposed to become prominent physical tangible equipment. In fact, according to Ghazali, "speech and thought exist without listener and transmitter as well". Thus speaking like inner monologue is a sign of this situation. It is an explanatory reason that speech and thought are the essential qualities for man. For example, a baby who has not spoken yet is a potential substance speaking and thinking even in the foetus. Other circumstances are supposed to become fact to actualize it verbally. But utterance requires an address and the existence of a listener (p. 58).

As a follower of Ghazali on some views, Fahreddin Razi is one of the thinkers exploring this issue in a semantic way. As for Razi he makes clear the difference between meaning and knowledge, utterance demonstrates referred meaning, which leads out of a necessity or desire in the nafs(mind). For instance, when one says "I would like water", he feels like a necessity, desire or request related to the feeling in his nafs. This inner cognitive situation is naturally different from the physical qualities such as voice and letter of utterance. Linguistic utterance is outpouring of the inner attitude. In this respect Razi makes four deductions from the speech act of the ordering "do!":

(1) The ordering "do!" refers to a desire in the heart. Denotation and referred, which means the utterance of order acquisition and the desire, have different natural form from each other.

(2) The utterance of a request might change along with time, place, speaker and language while the mental request does not change. Therefore, what does not change is an inner meaning that is common and shareable to be needed to reach by using all linguistic equipment. It is also valid to understand God's will from his utterance.

(3) Before the ordering "do!" gains a meaning of consensus in society, performance of the order does not mean inner distinctive command. Moreover, the meaning told by someone takes a shape with his inner 
intention or desire. The speech act of ordering corresponding to inner request and desire, according to Razi, is what is essential and stable. It does not depend on a rule or a consensus of the language in society. However, utterance of the language depends on the social usage and rules.

(4) The fourth reason has a strong relationship with the third one, but an important difference in a semantic way. For Razi the relationship of utterance and referred meaning is arbitrary as in the approach of Saussure. Utterance (Saussure called this hearing-image) used for inner meaning does not change the primary meaning. For instance, while "did" (fa'ala) and "doing" (yaf'alu) are used for declarative in a grammatical way, "do!" (if'al) for ordering and "do not do!" (la taf'al) for prohibition are used for the state of grammatical forms. However, Razi thinks grammatically of the opposite way, which means that "do!" and "do not do!" used for declarative expression, and "did" and "doing" used for ordering and prohibition are settled with consensually. A possible situation could have existed in the usage of language, but these intentional responses will not have changed. Whatever the state of expression of ordering and declaration is, the reality of request instead of declaration and declaration instead of ordering or request do not replace an inner meaning. Likewise, the reality of semantics is different from this utterance and statement. Linguistic expressions refers to just the realities mentioned before (Razi, n.d., pp. 53-54).

After this stage, Razi investigates again what the nature of request or declaration is. Because according to Razi, this mental content generally confuses with the resemblance of knowledge and belief. But, clear knowledge or even lots of contents that could not reach the level of belief in the people's mind might be found. As we deal with the example of Razi above again, one can say "the universe is eternal" even though he does not have any idea about that. For that reason, there is no point in having a knowledge or belief related to that. When the mind has a relationship between diverse concepts and propositions, it can make a right or wrong association. False judgment results from false association. These judgment sentences related to that are not the expressions of knowledge and belief. They are just judgment taken a form by the mind (Razi, p. 54).

Razi asks a question whether all these kinds of judgments are just mental constructions, and states that we can actually handle this problem as a mental construction although that can be an object of request and will. In this approach, Razi supports an idea that semantic objects which have a different meaning from knowledge are cognitive circumstances leading to request and will. "The request settled into the nafs and the tendency in to the heart is different from the decision" (p. 54). Consequently, intentional/mental contents might not be always equal with knowledge, decision, and belief. They are not also linguistic expressions uttered by speaker. So what is it?

For Razi, such a judgment as "Zayd stood up!" is not a intentional content in terms of knowledge and the will (p. 54). Hence, intentional contents that the speaker's desire, intention, and request head towards should be parted from the faith and knowledge in general. In other words, the all intentional contents may not be only knowledge and faiths. There can be other cognitive situations which are objects of desire, request or need. That distinction basically is based on the definition that Razi refers to knowledge. Razi differentiates epistemic concepts such as truth, certainty, knowledge, faith and judgment from the meaning and related judgment in terms of semantics. While knowledge is about certainty and truth that certainty is not asked for all the mental contents and judgments. Mind gathers up judgment true or wrong, but because of the fact that wrong phrases conclude as wrong judgment, it is not expected to emerge as a true faith or knowledge from a wrong judgment (p. 55). These explanations show the relation between epistemology and semantic that Razi indicates by pointing out the distinction between them. Razi argues the approach of Ahl us-Sunnah in general and he both 
makes semantic analysis on the subject and criticizes at some points. He also stands out the points that Mu'tazila is being logical. From Razi's such explanation, it is seen that his basic criticism has focused on Mu'tazila's mistaking of epistemology and semantic.

While kalam-1 lafzi (utterance) in Ahl us-Sunnah as mentioned by Ghazali in detail is related to mind/thought from one aspect (as said by Saussur that beside physical dimention it is also mainly spritual in auditory image), from other aspect it emerges with physical features as sound and letter. At this point, it is the intentional situation that the spritual (nafsi) one carries out the physical one. With such an aspect, this approach of Searle is worth sharing: "the speaker's original and substantive intention of thought is transmitted to words, sentences, signs, symbols, etc." (Searle, 1991, p. 83). The point that Ahl us-Sunnah and a thinker like Searle make can be summarized as the surplus thing adding to the physical/lingual one "intentional content" (Searle, 1991, p. 87).

Ahl us-Sunnah theologians - as seen in Ghazali and Razi - claim that the signs defined as the verbal dimension of language are formed with the speaker's intention and purpose, and they define it as "referred meaning" (madlul mana). Mental/inner situations such as intention, purpose, request, and desire are based on knowledge and the will but not come down to them. With the light of the explanations above, the definition "determined meaning" (qaim bi an-nafs) made by kalam thinkers let meaning explain at the base of the intentionality. ${ }^{5}$ According to Ici, the intention of putting a thing (an argument) into words shows the referred that is a particular kind of intention, request, desire or purpose which are differentiated from other meanings by forming at speaker's mind (Al-Ici, n.d., p. 294).

This approach seems to be corresponding to modern philosophers like Grice who put forward the speaker's intention. The intention of the speaker that does not coincide with the every time said expression and the reason of the claims. Grice points out that the meaning of an expression such as a word or sentence is not akin to the mentioned meaning with the expression in question (Grice, 1991, p. 117). The distinction of "the natural meaning" and "unnatural meaning" made by Grice aims at clarifying that. Hence, communication carries out over the unnatural meaning by adding purpose to natural meaning. In this case, the meaning of a lingual unit in any natural language obviously or insinuate do not depend on the purposes and intentions of the speaker who puts them into words. On the contrary, such kind of meaning has mainly formed with conventional usage and lingual rules that determined by one who used the language previously (Dawis, 2003, p. 24). So, the intentions and purposes of the speaker can carry out with numerous and different ways over standardized language. According to Grice, the speaker, by fulfilling conventional conditions of utterances acquisition, makes the conventional meaning a part of the speaker's meaning, as well (Grice, 1991, pp. 118-122).

Kalam-i lafzi(utterance) and kalam-i nafsi (inner speech) in the approach of Ahl us-Sunnah are fairly close to this distinction. Wheras kalam-i lafzi refers to social, conventional thereby standard meaning which is independent from the speaker's intention, kalam-i nefsi defines the speaker's desire, purpose, request, and intention being referred/transmitted over kalam-i lafzi.

For Saussure, "language" being two units of the lingual ability comprises the primary unit because of being social, yet the speech acts (parole) having individual and mental features has a secondary significance (Saussure, 1959, pp. 13-15). However, in the approach of Ahl us-Sunnah theologians, the roles almost change

\footnotetext{
5 At the meaning from the point view of Searle, mental attitude which described by Searle also as "network connections" such as purpose, request, desire, wish, expect which above the speech are gathered under the name of intentionality (Searle, 1991, pp. 28-29).
} 
and the cognitive attributed speech or meaning where the speaker's intentions and purposes are at the centre gains significance at primary level. The social aspect of conventional language indicates changes with respect to time, place, and communities. That lingual dimension called utterence (lafzun) has a secondary and instrumental value. Therefore, the psychological base of the meaning that based on the intention of the speaker.

At this context, Ahl us-Sunnah has to face with the problem of degrading the meaning to subjective and psychological one even if it is logical and right when arguing the existence of the cognitive dimension of meaning. Forasmuch, the claim that the meaning comprises mental content will have resulted in explaining the meaning especially reduction with disregarding fairly the role of the language and exterior factors of language. Thus, according to Ahl us-Sunnah approach, the fact that language is a social institution, its conventional dimension and social usage are mainly disregarded because of the power of emphasis that made the speaker's intention. Thus, these regarded points have been incurred to the convulsive criticisms of Mu'tazila as in the paragraphs we will elaborate on.

One of the main features coming forward that we have discussed in mentalistic/intentional approach of Ahl us-Sunnah theologians is that the meaning which being essential two components of the speech has a mental/inner character. The second one is the aformentioned inner meaning that gives the utter (lafzun) naturally priority. And the third common feature is that the utterance has an instrumental role in transmitting the meaning. According to this, the meaning materializes basically over the language that is the instrument of the communication towards the speaker's intention, purpose, and requests.

\section{Main Opposing Approach Mu'tazila: Meaning Within Rules of Language and Its Conventional Using}

Unlike the views of Ahl us-Sunnah theologians, Mu'tazila theologians argue that the meaning should not be searched for anywhere else-institutional features such as voice, word, grammar, syntax, and convention-sociability. So far as the meaning/speech materializes with its own rules and conventional use of language; a kalam which is mental (nafsi) cannot also be justified.

Such a kind of explanation means to claim a new view against the traditional approach which is dated to Aristotele, coming into focus with the thick lines especially in the Medieval Ages of the West. Then, according to the traditional approach, the meaning prominences utterence (lafzî) one and utterence exhibits only an instrumental significance in order to transmit that inner meaning. Mu'tazila, by reversing merely this approach, argues that the meaning can be explained just only based on the rules of language (grammar) and social convention.

When objecting to inner speech/meaning at the beginning, Qadı indicates some features of language that he has seen as intrinsic in defining language. According to this, the speech is an act which concretise in a particular place and physical conditions, consisting of particular differential and sequential letters that will separate it from the non-word one, perceiving with substantial sense, coming up in lingual rules and with these features carrying an useful meaning (content) for the hearer and the speaker (Qad1, 1961, pp. 84-85). The fact that Mu'tazila takes the word as an act emerges as a basic differentiation against Ahl us-Sunnah thinkers who take the speech especially as an essential attribute of the speaker. Actually, this differentiation shows that Ahl us-Sunnah prioritise "language ability" but Mu'tazila prioritize the speech acts/utterences which is the accruing situation of this ability for every individual. However, for Mu'tazila, the kalam and the word intertwine. Forasmuch, it cannot be mentioned a meaning which is independent from lingual features such as lafiz, voice, 
letter, etc. Everything which is uttered is not speech or word, what makes it word is being meaningful (Qad1, 1961, p. 6). Accordingly, if we summarize the definition "language is an act which is comprised from regular letters and voices, expressing a certain meaning/benefit perceiving with substantial senses occurring in a particular place" (Qad1, 1961, p. 84). According to Qad1 who argues that in the definition of the speech (kalam), voice, utterence (lafzun), and meaning should be considered together, the fact that person has quality of speech can only be known with the aspect of being heart, receptive of the word (1961, p. 63).

According to Qad1, word is a realm of action that the subject acts out (Qad1, 1988, p. 537). Language, though, is a regular structure composed of rules related to a clear grammar structure. Letter and voices become meaningful fragments in this structure. Otherwise, for instance, the letters of "z-e-y-d" composing the name of ZEYD could have had meaningless order in the form of "d-z-y-e" (Qad1, 1961, pp. 16-18). Therefore, grammar and syntax are obligatory-structural prerequisites of semantics. The more basic structural quality that makes word understandable and wording is the conventional feature of language. It means that words are signified and used before for clear meanings accepted as social. This approach reminds of Wittgenstein's words that explain language as regular rules, usage and social agreement: "every sentence in our language 'is in order as it is'...so there must be perfect order even in the vaguest sentence" (Wittgenstein, 1968, pp. 98/45e).

That word is signified for a clear meaning (social agreement) is a major condition which makes it understandable, beneficial and correct for others. Qadı states that linguistic agreement is inevitable for social agreement and communication as Lewis's description about agreement known as social compromising in an unidentified way. "A population's common use of someone language is a convention" (Lewis, 1969, p. 49). Likewise, getting to know intention and meaning is related to know beyond word and names, which means in principle what meaning is stated by these linguistic fragments and how they are used in society (Qad1, 1961, pp. 1-3). Because, not getting to know that hinders the access of speaker's intention, which means that it obstructs the process of getting to know what the real meaning is (Qad1, 1961, pp. 101-102).

In summary, according to Qad1, since word stated as conventional in terms of uttering a meaning requires linguistic orderliness during existing, the speech cannot be inner meaning (Qad1, 1961, p. 163). In this case, since meaning comes true and visible with word, it is ridiculous to talk about a word referring to letters in the mind. For that reason, it is a contradiction claim that meaning has orderliness in the nafs before uttering. It can be stated as monologue (Qad1, 1961, pp. 16, 18; 1988, p. 533). As we observe the explanation above, Qad1 mentions that meaning is structural rules based on linguistic agreement and its social function. Like Wittgenstein's famous quote "look at the usage, not meaning", Qad1 states that they abstain from a description of word based on meaning, and they prefer a description of "word is usage of utterance" in his work known as Şarh'ul Usul'ul Hamse (1988, p. 534).

One of the significant factors in Qadı's approach is the acceptance of these linguistic features completely on the bases of naturalist-experimentalist. It seems like the nature of language is a natural result of rules, social agreement and its usage. The point of view resembles Wittgenstein's approach that it is stated that words are like physical signs such as smiling, weeping, and crying. And all these signs' meaning are connected with linguistic usage (Haight, 1976, pp. 240-244). It is possible to see, in the further level, Quine who explains the trilogy of mind, behavior and psychology degrades in the base of biological at last. According to Quine, language is a tendency system based on verbal behavior (Quine, 1993, pp. 80-83). According to Qad1, in this case, language has a reality that is made understandable with the action of looking and the action of hearing like color and different perceptional events. The subject of perception is not only voice but also all other meaningful 
fragments related to the word. Since meaning does not mean something imprisoned in the mind, it can be possible to be understood on the condition that we make it utter (Qad1, 1961, pp. 14-18, 193).

Unless word contains a cognitive content like Qadı's approach, how come to attribute a meaning to the words called as physical stuffs in principle? Since the major problem to be tried to answer in linguistic philosophy as Alston draws attention as well is how the physical elements become meaningful contents (Alston, 1964, p. 3). Qadı's answer to this question is similar to the approaches that meaning becomes meaningful with usage and social agreement. Likewise, the feature of conventional is required not only for basic usage but also how to be uttered with pronounce and the concept of enunciating (Qad1, 1961, p. 261). For that reason, combining with voice and word together in a clear structure (syntax rules) is mandatory but not enough of a condition for meaning. They are also supplementary elements for how to use them conventionally in society at the same time. Likewise, according to Quine, linguistic response and its reactions do not exist at random. Accordingly, there is also criterion against behaviors based on tendencies and all of them are identified in society (Quine, 1993, pp. 88-89).

The social-conventional quality of language is a mandatory condition to provide communication between individuals. In addition to that, intention of the individuals plays an important role into the usage of language and even sometimes it has a clear part exceeding by socially. In this point, Qadı takes a step in the way of thinking, and states that meaning arises from knowledge and based on this knowledge making judgement via will. As we said before, Ahl us-Sunnah mentioned about knowledge and will as a background of cognitive contents. But this background was used to strengthen the mental/inner meaning. According to Qad1, neither meaning/speech nor inner contents is knowledge and will. For Qad1, the relationship between inner speech (kelam-1 nafsi) and utterance can be proved with neither a priori nor something empirical. For that reason, denotation of utterance has a role with just denotation of knowledge and will. For instance, the expression "I am going to a city" means that I have a will and knowledge into myself like into the situation of "go to the city" (Qad1, 1961, p. 18). I think Qad1 puts forward the will instead of cognitive intentionality in addition to knowledge to determine the content of sentence, that's why; it requires epistemologically a clear request in terms of judgment statement's element of supplementary knowledge. In other words, while linguistic-intellectual equivalent of cognitive tendency exists as meaning, the will referring to a decision maker power is associated with the knowledge that has more power and clearness than the meaning. The level of meaning shaped in the act of statements into the language has an epistemological value at the same time.

For that reason, it is determined that Qadı's approach which is the nature of meaning is based on directly knowledge instead of adopting cognitive contents such as his conception, idea, and thought as interm-phase. It is the point of semantic that is an explanation attempt in the base of epistemology. In other words, denotation of linguistic/verbal refers directly to the content of knowledge instead of a mental/inner meaning. It is said that Qadı's approach has a significant role in terms of objectiveness of meaning. In summary, they are actually sense of social agreement and informational background. While the first one seems like obligatory for sharing the meaning and opportunity of communication, the second one aims at explaining with content of knowledge based on more objective ground for meaning instead of mental contents that is subjective (like "idea" in the approach of Lock). When knowledge has a relation with reality, it becomes objective and open to transfer with shareable features by others. The issue needed to be faced here will be degrading semantics into the epistemology. Does making sense of an expression always mean that it is knowledge worthy? Can senselessness be equal with trueness? 
I think that the basic problem of Qadı's approach we gave this example for the point of view of Mu'tazila is that he ignores significantly contribution the speaker made for meaning. Meaning may not be always equal with knowledge; at the same time what reached with being understood may not be always equal with a content of knowledge. On the other hand, it can be defended what claimed does not constitute disability for objectiveness of meaning in addition to accepting that speaker's intention and purpose have an important role at signifying the meaning.

\section{Conclusion}

Ahl us-Sunnah theologians explain speech/meaning with mental tendencies such as speaker's intention, purpose, desire, and request. The physical part of speech (utterance) has an instrumental function to reveal these cognitive contents and transfer to the listener. Utterance is indication which means it refers to the inner meaning that is denotation. Utterance changes from society to society and from time to time at the same time. Denotation meaning is always permanent referring to what is actually propositional, and also it is the content wanted to reach by words/utterance. Ahl us-Sunnah, with its approach, divine speech is used to prove that correct understanding of divine speech means to comprehend the divine intention. It is a transition to comprehension and interpretation hermeneutic from over this linguistic approach. Moreover, it is a field of more detailed and different research.

Mu'tazila we dealt with the example of Qadı puts forward conventional structure of language against the approach of Ahl us-Sunnah. Meaning is not mental, just a usage accepted before in society within the scope of language rules that can give us the meaning of words and sentences. It is beside the point to mention about an inner meaning/speech. The determiner of meaning is speaker's knowledge background at the same time.

While meaning has subjective features psychologically in the approach of Ahl us-Sunnah, references with the knowledge and sense of community have more objective level to the meaning in point of view of Mu'tazila. While Mu'tazila pushes speaker's contribution to the meaning into the background, Ahl us-Sunnah has a low importance over meaning based on social agreement. Ahl us-Sunnah with its approaches resembles with the approaches related to the representation of language and intellectualism of meaning that is defended by thinkers beginning from Ariostotele such as Locke, Grice, and Searle in all different parts. On the other hand, Mu'tazila resembles with particularly beginning from Wittgenstein's approaches based on meaning within the language rules and the social usage. It is useful to be reminded that all these results came through in terms of language and semantics of Ahl us-Sunnah and Mu'tazila are directly connected with two different perspectives into the major theological problems related to nature of God and his adjectives.

\section{References}

Alexander, P. (1985). Ideas, qualities and corpuscles. Cambridge: Cambridge University Press.

Al-Ghazali, E. H. M. (1998). Kitabu'l i'qtisad fi'l-i'tiqad (The book on the economy of creed). Beirut: Dar'ul-Kutubu'l İlmiyyah.

Al-Ici, A. İ. A. (1992). Al-mawaklf fi ilm'il-kalam (Halting stations on theology). Beirut: Allamu'l-Kutub.

Alston, W. (1964). Philosophy of languagae. London: Prentice-Hall.

Aristotele. (2002). Yorum üzerine (Peri hermeneias) (Saffet Babür: trans. in Turkish). Ankara: İmge.

Ar-Râzi, F. (n.d.). Halku'ul Qur'an baynal Mu'tazilah we Ahli's-Sunnah (Qur'anic createdness between Mu'tazilah and Ahlu's-Sunnah). Dr. Ahmad Hicazi as-Saqa. (vrf.), Beirut: Daru'l Cayla.

Baqillani, Q. B. (1986). Al-inșāf fìmā yajibu i'tiqāduhu wa-lā yajūzu al-jahl bihi fì 'ilm al-kalām (Fairness on what must be known and inappropriatness in cases of ignorance on theology). Imamu'd-Din Ahmad Haydar (vrf.), Beirut: Alamu'l Kutub. 
Bor, I. (2014). Analitik dil felsefesinde dil, düşünce ve anlam (Language, thought and meaning in analitical philosophy). Ankara: Elis.

Dawis, W. A. (2003). Meaning, expression and thought. Cambridge: Cambridge University Press.

Grice, P. (1991). Studies in the way of words. Cambridge: Harward University Press.

Guwaini, A. (1992). Kitabu'l irşad qawaid-il edilleti fi usuli'l-i'tiqad (Guide book on the rules of proofs for the principles of creeds). As'ad Tamim (vrf.), Beirut: Muassasatu'l Kutubu's-Saqafiyyah.

Haight, D. (1976). The source of linguistic meaning. Philosophy and phenomenological research, 2(37), 239-247.

Kretzman, N. (1967). History of semantic. In P. Edwards (Ed.), Encyclopedia of philosophy (vol. 5). New York: The Macmilan Company \& Free Press.

Landsman, C. (1976). Locke's theory of meaning. Journal of the history of philosophy, 14(1), 23-35.

Lewis, D. K. (1969). Convention: A philosophical study. Cambridge: Cambridge University Press.

Putnam, H. (1993). Meaning and reference. In A. W. Moore (Ed.), Meaning and reference (pp. 150-162). Oxford: Oxford University Press.

Qad1, A. H. (1961). Al-Muğni fi abwabi't-tawhid wa'l-adl (A comprehensive study on oneness and justice). Abdulhalim Mahmud, Suleyman Dunya. (vrf.), Qairo: Dar'ul-Misriyye.

Qad1, A. H. (1988). Sharhu'l Usul'ul-Hamsa (Commentary on the five principles). Dr. A. Karim Osman \& Ahmad Huseyin b. ebu Hashim (vrf.), Qairo: Mektebetu'l Wehbe.

Quine, W. V. (1993). Mind and verbal dispositon. In A. W. Moore (Ed.), Meaning and reference. Oxford: Oxford University Press.

Saussure, F. D. (1959). Course in general linguistics (Wade Baskin, trans.). New York, London, Toronto: McGraw-Hill Book Company.

Searle, J. R. (1991). Intentionality: an essay in the philosophy of mind. Cambridge: Cambridge University Press. 